\title{
English Extensive Reading in the School Library with the English Department
}

\author{
Tamao Eryu Noriko Muramatsu \\ Meiji University Meiji High School Meiji Junior High School \\ 4-23-25 Fujimicho Chofu, Tokyo 182-0033 \\ Japan \\ eryutamao@hotmail.com \\ noriko.peace.maker@gmail.com
}

\begin{abstract}
In this study, we describe how the school library collaborated with the English Department with English Extensive Reading (EER) programs. In many schools in Japan, English books are kept in the English teachers' room which makes access to the books difficult for students because these rooms are locked when the teacher is not around. We discuss how placing the English books in the library have helped both students and teachers in conducting the EER lessons and how teachers became a closer team through EER programs. We also explain other effects that this collaboration between the teacher librarian and the English teachers has brought, which was making an environment where collaboration can occur much easier in the whole school.
\end{abstract}

Keywords: English Extensive Reading, English Department teacher, Teacher Librarian, Collaboration, School Library 


\section{Introduction}

According to the School Library Survey Report 2015 by the Japan School Library Association (JSLA), the average books in the school library are 11,929 in Junior High School and 25,347 in high School. Compared to the School Library Media Standard released in 2000, this average shows that sufficiency rate is $59 \%$ in Junior high school, $99 \%$ in high schools, if the school has only three classes and 120 students, but most schools are much larger than this number meaning that most Junior High Schools and High Schools do not meet the sufficiency rate (JSLA research division, 2015, p.39-43). This low rate also explains that school libraries do not have enough budget or space to become the center of reading or learning.

As is the reality, many schools have taken in English Extensive Reading (EER) programs in the school since 2000. EER literally means reading a lot in English to enforce students' English ability. However, with limited space and budget in the library, this program cannot be conducted by the school library alone. With the growing interest in EER, many public schools and some private schools succeeded in getting the budget to purchase enough English books to conduct the program. But since English teachers do not have the knowledge to classify books or how to manage the book stock of a library, most schools keep these books in the English teacher's room or in the English classrooms which are usually locked when there isn't a lesson.

Meiji University Meiji High School Meiji Junior High School (Meiji Koko Chugakko, MKC) is a private co-ed school attached to Meiji University. It has a total of 1,300 students; 500 students age 12-14 in Junior high school, 800 students age 15-17 in High school. The school library has a total of 60,000 books in Japanese and 6,000 English books. It is run by one teacher librarian and two non-regular library staff. The annual lessons conducted in the library are about 280 hours out of about 1,250 hours a year. $92.5 \%$ of high school students are accepted to Meiji University which allows students to study all of the subjects and not focus on only the subjects needed for the university entrance exams. Our students must pass Grade 2 in "The EIKEN Test in Practical English Proficiency" (B1 level on CEFR) along with a score of over 450 (full mark is 990) on the TOEIC test (A2 level on CEFR). According to a survey conducted by the Ministry of Education, Culture, Sports, Science and Technology, 2015, the rate of high school students who have achieved this standard is $11.9 \%$ in Japan. The English Department in MKC has worked hard to make all the students reach the obligation and as a result, $97.5 \%$ of students have passed the EIKEN Test and scored more than 450 in TOEIC.

EER is one of the programs adapted by the English Department in the English curriculum. In $\mathrm{MKC}$, this program is conducted by both the library and the English Department. After some 
discussions between the library and the English Department over budget, space, and responsible roles, the program started much smoother than first anticipated and has been expanding and revised every year. In this report, we will explain how the library and the English Department have worked together to make a successful EER program in the school. Following our way, we believe the EER can be adapted in schools in other non-English speaking countries.

In this paper, when we refer to things done in our school, we will use the term 'teacher librarian' and when we explain about experts in a school library other than in MKC, the term 'school library staff' will be used.

\section{Extensive Reading in the Second Language}

Free Voluntary reading (FVR) is 'one of the most powerful tools we have in language education' (Krashen, 2004, p.1). Many researchers have explained how effective they are in education. In this paper, we will explain the practical things we've done to integrate extensive reading in the second language, in this case, English. 'Integrating extensive reading into second language programs has four broad ways; as a separate course, as part of an existing reading course, as a noncredit addition to an existing course, or as an extracurricular activity' (Day \& Bamford, 1998, p.41). In MKC, we integrate EER as part of an existing reading course.

In Japan, EER was introduced by Sakai in his book "Kaidoku Hyakumango, Pleasure Reading One Million Words" (Sakai, 2002). His method of EER is aimed to read English without translation, so students start with very simple stories such as picture books. He also advocates three standards when reading. 1) Don't use the dictionary, 2) Ignore words you don't understand, 3) Change books if you feel it's boring. Because the method was simple, it quickly became popular among adults who want to brush up their English and just two years after the book came out, the Extensive Reading Association was founded in 2004. In 2009, EER was added to the Koko Gakushu Shido Yoryo, a teaching guideline by the government. In Japan, all schools, public or private, must follow this guideline in their curriculum and this was another reason EER attracted so much attention. EER for adults have a different meaning compared with EER for students in Junior high school and High school. Students are still learning new grammar and vocabulary and EER would be an advanced program where students need help from teachers. This is one of the big reasons that EER should be collaborated with the school library and the English Department.

Many schools which started the EER program purchase Leveled Readers (LR) or Graded Readers (GR). The English in these books are controlled and consists of $300-1,000$ words. These books sometimes have comprehension questions or glossary on the back of the book. 
In many cases, these books are read only in the classroom and students are not allowed to borrow them. So choosing a book and reading is mostly done during lessons. The books are carried in a basket to the classrooms and are collected when the lesson is over. They are then returned to the English Teachers' room or if the school has an English Room, they are placed back there. Both rooms are likely to be locked when there aren't any lessons.

\section{EER in the School Library}

In Japanese schools, classrooms are used by the students and teachers are stationed in the teachers' room. When the lesson starts, it is the teachers who move to the classrooms and not the students. Having an English library in one of the teacher's classrooms does not happen. Instead, the teachers carry whatever they need to conduct a 50 minute lesson. So to have an EER lesson, the teacher must bring all the English books they have in the school. This is another good reason to have the English books in the school library. We can assemble the students in the library when we have an EER lesson.

In many schools, EER is considered only as a part of English education only by the English teachers. Many school library staffs are not so strong in English and do not like to have English books in the library. So the English books are purchased by the English Department, used only in English lessons and put away after the lessons are over. 'Overly restricting access to the materials makes it hard for students to browse and select reading matter that interests them - a key aspect of an extensive reading program' (Day\& Bamford, 1998, p.113). So as Sakai \& Nishizawa (2014) explains, some school libraries make an English library corner or even an English library room inside the school library but the English books are usually just for reading in the library and not for circulation, or even considered as library books. We have asked some of these school libraries about this fact. The reason why the books are not in circulation has several reasons. First, they don't have enough books and if they are borrowed, the next class will have book shortage. Some students will not handle books carefully. One school answered that students will read in class, but will not read outside class anyways. This does not happen in MKC. There are reluctant readers who will not borrow books, but many students tend to enjoy reading outside class.

The merits of not being included as library books are as follows; 1) the English books are not purchased by the library, so the library doesn't need to get budget for them. 2) the school library staff will not be required any English. 3) the students cannot borrow them, but have free access to English books. The demerits are; 1 ) the school library staff cannot be involved in students' reading activities. 2) reading time is limited. Students can read only during English lessons or while the library is open. 3) the English teachers cannot learn what level books are read or how much was actually read by the students. 4) because they are not in circulation, 
there is no record of popular books or knowing what books are popular among students in each grade or English level.

In MKC, EER started among a few English teachers interested in this method in 2006, and the books purchased were kept in a basket which was put back in the English teacher's room when the lessons were over. The collaboration with the school library and the English Department started in 2009 (Eryu \& Muramatsu, 2012, p.76-79). Before starting the collaboration, the teacher librarian and the English teacher had a discussion over roles, merits, and how to overcome any demerits. Through this discussion, we had come to finding only merits and keep a good relationship. The roles discussed are as follows;

1) Budget for any English book will be from the English Department.

Any budget for English books is from the English Department's budget given annually from the school. Also the English teachers give a part of their research funding that is given annually from the school. We were also lucky to get a supplementary budget for three years, allowing us to purchase more books and some book trucks, expanding the library in a short time. In earning the supplementary budget, the teacher librarian also requested to the school to prepare the budget for the English Department.

2) Choosing English books will be a discussion with the English teacher and the teacher librarian. But the actual purchasing will be done by the English Department. In Japan, purchasing English books is not easy. Most book stores have LR or GR but finding other titles and genres is mainly on the Internet. Also, few English teachers have the experience of choosing books for a library. So the teacher librarian introduced book stores that come regularly to the school, and web sites that would help the English teachers to choose books. Other practical work, such as making orders to the book stores or how to pay for the books was lectured to the English teachers.

3) Making the catalog and any physical processing will be done by the English Department. MARC (machine readable catalog) for English books hardly exists in Japan. Other information on the book itself, such as level, word count, or any other content note does not exist as data. When the English books arrive, the English teachers make the necessary catalogue data manually. Then, the teacher librarian imports the data into the library management system. Call number labels will be printed out in the library and given to the English teachers. The English teachers put the call number labels, barcode labels, a color sticker to show the level of the book which also indicates word count of the book, and put on a plastic cover if needed on each book. The reason to show the level and the word count of a book is because it is useful for the students. 'It is essential that students have a way of knowing which books are 
linguistically suitable for them. Teachers may have to do a lot of reading in order to decide the levels to assign the books in the library' (Day\& Bamford, 1998, p.112).

4) Circulation of the English books will be done by the teacher librarian and the non-regular library staffs but returning books into their shelves will be done by the English teachers.

The English teachers take turns in returning the English books to the shelves. All the English teachers will come to the library at least once a week to do the job. In this way, the teacher librarian can have a short talk with all the English teachers. The English teachers learn what books were borrowed through this job and also have a chance to observe or talk with students choosing books.

5) All circulation data concerning the English books will be open to the English teachers. In MKC, the English books are a deposit of the English Department, and the library helps with the circulation. So any data the English teacher requests to the library will be given. The English teachers use this data to revise the EER program, for example to see when the books are most borrowed and read or what books are popular which will be a hint when purchasing new books.

6) Any displays inside the library will be done by both the teacher librarian and the English teachers.

The displays are not just to attract attention, but to support students choose books that interest them or to find the suitable level. For example, displaying the English book beside the Japanese translation book is one way to encourage students to read a little challenging book. If the student has read the Japanese version when they were in elementary school, it will encourage them to read them in English. English teachers don't know which of the Japanese version is in the school library, so the teacher librarian needs to help. Other displays such as making a blurb or a flyer written by teachers or other students are displayed near the recommended English books.

All of the above continues to this day. English teachers are required to do some parts of the library work, but this allows the teacher librarian to do all the regular library work. If the teacher librarian has to do all the extra work for the English books, EER might trail off as it would be too much work for the teacher librarian. There is only one teacher librarian but there are 17 English teachers in the school which means each teacher's work is not a heavy load. Husid points out that 'teachers are already busy and fear that collaborating will mean more work. Demonstrate that collaboration will add value to what they are already doing and reduce their workload' (Husid, 2013, p.44). 
To find shelving space is another big issue. We have come to the conclusion to use one full shelf installed in the library, four book trucks and 15 small shelves with wheels in the library. Placing books on the book truck is convenient for English teachers to bring the whole set of English books to the classrooms, especially when the library is used for a different lesson. There are 5,000 books always in the library and 1,000 stored in the English room. The books usually stored in the English room are duplicate books, and are moved into the library before summer and spring vacations when most of the books would be borrowed. Every year, new books are purchased and old books or unpopular titles are moved into the English room. In this way we can deal with spacing problems. This allows the students to access to new books, the shelves will not be packed tightly and being able to do so, encourages them to come to the library and enjoy choosing books.

\section{Results Gained Through Collaboration}

Here are the merits we gained through this collaboration.

1) Merits for the School Library

- More students use the school library.

- Roles of the school library is understood among English teachers.

- Other collaboration becomes easier to be practiced.

- Multiple approaches to students who overdue books or lost books.

- English ability is not an obligation for the school library staff.

- More Japanese (first language) books are borrowed.

2) Merits for the English Teacher

- Book circulation and management of the English books become a lot easier.

- Learn what genre is popular among students.

- Learn what level of books each grade reads.

- Unexperienced teachers can easily join the program.

- Lesson preparation for the program becomes less.

- Making a book log just for your students is easy because the data is in the library management system.

- English teachers can observe and have a talk with students when returning the books to the shelves.

3) Merits for the students

- Can access to the English books any time.

- Can see what other grades are reading.

- Finds a place to stay in the school. 
- Can feel English is not something to be scared of.

- Can get advice from other English teachers and the teacher librarian.

- Visits the library more often, and borrows books both in English and Japanese.

As it is written in the merits above, English teachers learn what books interest students and what don't. But some teachers know more about books and others don't. Also because the program is not so concrete, it is not always the same teacher that conducts the lessons. This sometimes makes it difficult to learn what the students want to read right now. Day \& Bamford says that 'Teachers who are not sure what students will find interesting to read can observe or ask what their students read in their first language. They can also pay attention to what their students talk about and do in their free time' (Day \& Bamford,1998, p.110). The teacher librarian is perhaps the only teacher who can do this all the time. And we must also note that the English teachers themselves read more and borrow books from the library because they need to give advice on books to the students.

Day\& Bamford points out that students tend to use the library individually. 'This makes it difficult for them to suggest books to each other, and the excitement and stimulation of hands-on recommendation are lost. It also makes it harder for teachers to observe individual students engaged in the crucial activities of browsing and choosing books' (Day\& Bamford, 1998, p.113). It is the contrary in a Junior high school and High school library. When the lessons are done in the library, it allows students to suggest books to each other and share whatever they know about the book. The teacher librarian is always there to observe what students are browsing or choosing. Also as mentioned in the merits above, students get advice from other English teachers when they are browsing and choosing outside class. Any comments or requests from other subject teachers or students are shared among all the English teachers through the teacher librarian.

\section{For a Successful Collaboration}

EER in MKC expanded and continued because the library and the English Department collaborated. The teacher librarian and the English teachers found more merits than they first thought. If this program was conducted alone, meaning only by the library or only by the English Department, we could not have succeeded. This collaboration strengthened our team work in the school and allowed other departments to collaborate with the library, too. Multiple educational supports for the students allow more learning opportunities.

Starting an EER Program in the library with the English Department has many obstacles to overcome. First, and probably the biggest issue is the budget. English books sold in Japan are priced three to four times higher than in the English countries. This means library budget 
is difficult to apply since even the Japanese books sufficiency rate is still not high enough. Second, for spacing, both the librarian and the English teacher should have a good talk and give ideas to each other to come to a good conclusion.

For collaboration to happen in the school, the following is essential;

1) to have the same goals,

2) understand the expertise of each other

3) always find time to have a short meeting to exchange information.

Having a frequent talk or discussion is a key in collaboration. Teachers are very busy, but there is always a way to find a short discussion time. These talks and discussions lead to trusting each other, makes planning time short and finding ideas to revise the program. When there is a small question, you must always ask each other without time lag. A good discussion before starting any program allows the program to go on successfully and we must always remember that these lead to good education for the students, which should always be the goal of any program in the school.

We agree that 'collaboration was thinking together and sharing resources and expertise to benefit themselves and their students'. And we experienced and understood that 'by working together toward a common goal, more interesting lessons were created. These types of lessons were designed to produce a higher level of understanding by students' (Montiel -Overall. 2008, p.149).

\section{Future Issues}

Finding middle level English books: Middle level meaning books for students in grade 5-6 in an English speaking country. For example, students request books written about law, or economics. Meiji University was founded as a law school and is strong in law, economics and commerce. But many books published in these areas are aimed for high school students to read in English speaking countries, that they are too difficult for Japanese high school students. To find English books in social science, science, and other related books is a struggle for Japanese schools. Book catalogs in these areas are not available and for teachers to find books in Japan is very difficult.

Audio: Many books have audio CDs sold along with the books. However students use iPods and other music devices. They do not have a CD player in their homes. Using CDs would allow the students to read more fluently and speedy, or read a book that is a little challenging for them to read on their own. Audio also help to finish reading a thick book. The other good effect is that reading with audio prevents students to translate everything into Japanese in 
their heads which will lead to understanding the content in English.

E-books: E-books may be easy for the students to borrow and return, but we think of this technology as a demerit for EER. First, it is troublesome to check the number of words and level of the English. Second, since students do not need to come to the library to borrow or return books, there will be less communication between the teacher librarian and students which will make it difficult to find out what they need. Also, English teachers will not have the work to return books on the shelves but will not understand what books are read among the students.

A non-regular library staff started to read English books during her free time when working in the library. After a year, she acquired the ability to read English books, and was able to give some advice to the students through her reading experience. This would certainly not have happened if the English books were not placed in the library. Other subject teachers interested in English also started to read English books as FVR. When students see teachers reading simple English books, they are motivated and sometimes proud that what they can read is more difficult than what the teacher was reading.

\section{Conclusion}

Through collaboration between the library and the English Department, the school became a "team of educators" and not individual teaching experts. It also lead to other styles of collaboration. When the educators become a team, curriculums become richer in contexts. Information Power indicates that 'working to establish links not only between the library media program and individual teachers but among the teachers themselves, the library media specialist encourages a culture of collaboration throughout the school.' 'Collaboration is a symbiotic process that requires active, genuine effort and commitment by all members of the instructional team' (AASL\&AECT, 1998, p.51).

In MKC, the team building between the school librarian and the English teachers made the English Department itself a closer team. For example, the English teachers plan the English curriculum for the year together, because they have to discuss materials, especially over EER. So now all the teachers in the department are involved. The English teachers work together to prepare new books, return books to the shelves and do an EER lesson as well as the normal English lessons using textbooks. Today, all the grades from Junior 1 to Senior 3 do some EER during the year although there isn't a concrete program.

Montiel-Overall goes on to say that;

'Working together all the time meant that the school environment encouraged joint 
planning.' 'In this atmosphere of collaboration, participants felt they could approach a colleague any time and any place to brainstorm, share ideas, or discuss a lesson.' 'Teachers and librarians established relationships to share ideas, mentor new teachers, and to socialize. Participants explained that the librarian helped establish relationships in the school environment because she worked with the whole faculty.' 'She built relationships so that she could work with teachers, which meant teachers got to know each other better (Montiel-Overall, 2008, p.150).

They also say that:

Research specifically related to those learners identified above as 21st-century students should be undertaken to determine the effect of TLC on improved language development, literacy. and other academic needs. Collaboration has the potential for changing teaching and learning (Montiel-Overall, 2005, p.44).

But, as Johnson cautions;

What everyone seems to forget is that collaboration is just one means (and not always the best one) of achieving a goal, not the goal itself. Too many library media center studies say 'such and such' led to greater collaboration. Big whoop. Did it lead to more measurable student learning? (Johnson, D. 2006, p.98).

In MKC, we have succeeded in what Cooper \& Bray (2011, p.54) says; 'making a good collaboration, having a positive impact on instructional programs and, ultimately, on the student achievement'.

For teachers to collaborate with the school library is a new and big issue. But the EER program can be started easily because lesson plans are not so concrete. English teachers can set the lessons flexibly, and this flexibility allows the EER programs to keep working. This connects to making a good relationship between the teacher librarian and the English teachers because there isn't so much pressure. A good relationship also connects to other literacy education collaboration.

In MKC, there are other collaborations with the library and the English Department. Such as preparing for an English speech, an English presentation, research works such as finding out about certain topics or learning about the background of a book that the students will read. We also realized that because students do not fear reading English books, they learn to use English resources when they are working on other subjects, for example when writing a report for science or social studies. 
Now in the school, with the teacher librarian in the center of collaboration, there are collaborations between other subjects, such as English with Social Studies and History, English with Japanese, Social Studies and History with Japanese and so on. EER program needs little energy to start but brings about a really valuable result. This may be the true meaning of placing the English books in the school library.

\section{References}

American Library Association of School Librarians \& Association for Educational Communications and Technology.(1998).Information Power: Building partnerships for learning. American Library Associations.

Cooper, O.P. \& Bray, M (2011, July). School Library Media Specialist-Teacher Collaboration: Characteristics, Challenges, Opportunities. TechTrends, 55(4), 48-54. Retrieved May 10,2016 from https://bcpslis.pbworks.com/w/file/fetch/87711244/collaboration.pdf.

Day, D. R. \& Bamford, J (1998). Extensive Reading in the Second Language Classroom. Cambridge University Press.

Eryu,T. \& Muramatsu,N. (2012,November). English Extensive Reading in Meiji University Meiji High School Meiji Junior High School; A study on how students choose books. Meiko Kenso(11), 75-95.

Husid, W. (2013, January). Collaboration: Make It Happen in Your School. Library Media Connection. 31(4),42-44. Retrieved May 22,2016 from https://alocke1. wikispaces.com/file/view/A+4.3+article+HUSID.pdf.

Johnson, D (2006,January). A Few Words About Collaboration. Library Media Connection, 24(4), 98. Retrieved May 10,2016 from http://web.a.ebscohost.com.ezproxy.tulips.tsukuba.ac.jp/ehost/pdfviewer/pdfviewer?vid $=6 \&$ sid=6b708c29-8f2a-4568-afd9-fde3e9411 ade\%40sessionmgr4005\&hid=4112.

JSLA research division（2015） . 2015 School Library Survey Report. School Library ,781,39-43.[in Japanese]

Krashen, S.D. (2004). The Power of Reading second edition. Heinemann.

Ministry of Education, Culture, Sports, Science and Technology(2015). Promotion Plan of Improve Students' English. Retrieved May 3, 2016 from MEXT Web site: http://www.mext.go.jp/a_menu/kokusai/gaikokugo/_icsFiles/afieldfile/2015/07/21/135 8906_01_1.pdf. [in Japanese] 
Montiel-Overall, P. (2005, July). A Theoretical Understanding of Teacher and Librarian

Collaboration(TLC).School Library Worldwide.11,.24-48. Retrieved May 3, 2016 from http://murraylib604.org/TheoreticalUnderstanding.pdf

Montiel-Overall, P. (2008). Teacher and Librarian Collaboration: A qualitative study. Library \& Information Science Research.30,145-155. Retrieved May 3, 2016 from http://ac.els-cdn.com/S074081880800011X/1-s2.0-S074081880800011X-main.pdf?_ti $d=4 f 9545 e 0-26 f 5-11$ e6-bb2c-00000aab0f6b\&acdnat=1464674752_ef95779be359837 $5 f 0 d 92 b c 0 d 3360032$.

Sakai, K. (2002). Kaidoku Hyakumango, Pleasure Reading One Million Words. Chikuma Shobo. [in Japanese]

Sakai, K. (2014). Toshokan tadoku e no Shoutai, Inviting English Extensive Reading in the Library. Japan School Library Association. [in Japanese]

\section{Biographical note}

Tamao Eryu has worked as a teacher librarian at Meiji University Meiji High School Meiji Junior High School (MKC) in Tokyo since 2007. She received her master's degree from the Graduate School of Library, Information and Media Studies. University of Tsukuba. Her main research is Teacher/Teacher Librarian Collaboration. Almost every day she has lessons with teachers and enjoy them. She wrote Information Literacy Teaching Activities for Teacher Librarian's Lessons. School Libraries in Tokyo, 2009, (45)22-31. Trend of Meiji High School Students' Graduation Thesis. Meiko Kenso.2011, (9)3-8. Eryu,T. \& Muramatsu,N. English Extensive Reading in MKC; A study on how students choose books. Meiko Kenso, 2012(11), 75-95. Expertise Required for School Library Staff Supporting Learning and Its Cultivation. Libraries today 2015, 53(1),19-24. Reading activities in MKC. Meiji University Library and Information Science Society Bulletin 2016,(7), 25-32. [all in Japanese]

Muramatsu, Noriko is an English teacher in Meiji University Meiji High School Meiji Junior High School. She majored in Second Language Acquisition. She has taught English in private schools for 16 years and has been working on EER (tadoku) in all of her teaching. She grew up in Canada where she learned to read. Her works are Eryu,T. \& Muramatsu,N. (2012).

English Extensive Reading in Meiji University Meiji High School Meiji Junior High School; A study on how students choose books. Meiko Kenso(11), 75-95., Extensive Reading Results of High School Students; Reports from Meiji University Meiji High School. Annual of the Teacher-Training Course at Meiji University (38), 191-202, 2015. [both in Japanese] 